\title{
Article
}

\section{The Automated External Defibrillator: Heterogeneity of Legislation, Mapping and Use across Europe. New Insights from the ENSURE Study}

\author{
Enrico Baldi ${ }^{1,2,3, *}$, Niccolò B. Grieco ${ }^{3,4}$, Giuseppe Ristagno ${ }^{3,5}$, Hajriz Alihodžić ${ }^{6}$, Valentine Canon ${ }^{7,8}$,

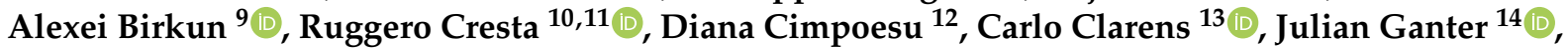 \\ Andrej Markota 15,16, Pierre Mols ${ }^{17}$ (D), Olympia Nikolaidou ${ }^{18}$, Martin Quinn 19, Violetta Raffay 20,21, \\ Fernando Rosell Ortiz ${ }^{22}$, Ari Salo ${ }^{23}$ (D) Remy Stieglis ${ }^{24}$, Anneli Strömsöe 25,26,27, Ingvild Tjelmeland ${ }^{28,29,30(D),}$ \\ Stefan Trenkler ${ }^{31}\left(\mathbb{D}\right.$, Jan Wnent ${ }^{30,32,33}$, Jan-Thorsten Grasner ${ }^{30,32}(\mathbb{D}$, Bernd W. Böttiger 34,35 (D) \\ and Simone Savastano ${ }^{3,36}$
}

\section{check for} updates

Citation: Baldi, E.; Grieco, N.B.; Ristagno, G.; Alihodžić, H.; Canon, V.; Birkun, A.; Cresta, R.; Cimpoesu, D.; Clarens, C.; Ganter, J.; et al. The Automated External Defibrillator: Heterogeneity of Legislation, Mapping and Use across Europe. New Insights from the ENSURE Study. J. Clin. Med. 2021, 10, 5018. https://doi.org/10.3390/jcm10215018

Academic Editor: Guillaume Debaty

Received: 8 October 2021

Accepted: 24 October 2021

Published: 28 October 2021

Publisher's Note: MDPI stays neutral with regard to jurisdictional claims in published maps and institutional affiliations.

Copyright: (c) 2021 by the authors. Licensee MDPI, Basel, Switzerland. This article is an open access article distributed under the terms and conditions of the Creative Commons Attribution (CC BY) license (https:// creativecommons.org/licenses/by/ $4.0 /)$.
Department of Molecular Medicine, Section of Cardiology, University of Pavia, 27100 Pavia, Italy

2 Cardiac Intensive Care Unit, Arrhythmia and Electrophysiology and Experimental Cardiology, Fondazione IRCCS Policlinico San Matteo, 27100 Pavia, Italy

3 Italian Resuscitation Council, 40128 Bologna, Italy; niccolo.grieco@gmail.com (N.B.G.); gristag@gmail.com (G.R.); s.savastano@smatteo.pv.it (S.S.)

4 Cardiology Department, Niguarda Hospital, 20162 Milan, Italy

5 Department of Pathophysiology and Transplantation, University of Milan, 20122 Milan, Italy

6 Emergency Medical Service, Public Institution Health Centre 'Dr. Mustafa Šehović' and Faculty of Medicine, University of Tuzla, 75000 Tuzla, Bosnia and Herzegovina; hajriz.a@hotmail.com

7 CHU Lille, ULR 2694-METRICS: Évaluation des Technologies de Santé et des Pratiques Médicales, University of Lille, F-59000 Lille, France; valentine.baert@univ-lille.fr

8 French National Out-of-Hospital Cardiac Arrest Registry-Registre Électronique des Arrêts Cardiaques, F-59000 Lille, France

9 Medical Academy Named after S. I. Georgievsky of V. I. Vernadsky Crimean Federal University, 95000 Simferopol, Russia; birkunalexei@gmail.com

10 Quality and Research Division, Federazione Cantonale Ticinese Servizi Ambulanza (FCTSA), 6500 Bellinzona, Switzerland; ruggero.cresta@fctsa.ch

11 Fondazione Ticino Cuore, 6900 Lugano, Switzerland

12 Emergency Department, Faculty of Medicine, "Grigore T. Popa” University of Medicine and Pharmacy, 700115 Iasi, Romania; dcimpoiesu@yahoo.com

13 Luxembourg Resuscitation Council, 2680 Luxembourg, Luxembourg; carlo.clarens@lrc.lu

14 Department of Cardiovascular Surgery, Faculty of Medicine, University Heart Center Freiburg, 79085 Freiburg, Germany; julian.ganter@uniklinik-freiburg.de

15 Slovenian Resuscitation Council, Slovenian Society of Emergency Medicine, 1000 Ljubljana, Slovenia; andrej.markota@ukc-mb.si

16 Medical Intensive Care Unit, University Medical Centre Maribor, 2000 Maribor, Slovenia

17 Service des Urgences et du SMUR, CHU Saint-Pierre, Université Libre de Bruxelles, 1000 Bruxelles, Belgium; pierre.mols@gmail.com

18 EMS-National Center for Emergency Care, 546 Thessaloniki, Greece; olynmed@yahoo.gr

19 Out-of-Hospital Cardiac Arrest Registry Steering Group, National University of Ireland,

H91 CF50 Galway, Ireland; martin.quinn@hse.ie

20 Department of Medicine, European University Cyprus, Nicosia 2404, Cyprus; violetta.raffay@gmail.com

21 Serbian Resuscitation Council, 21102 Novi Sad, Serbia

22 Servicio de Urgencias Médicas 061 La Rioja, 26007 Logroño, Spain; fernando.rosell@juntadeandalucia.es

23 Department of Emergency Medicine and Services, University of Helsinki and Helsinki University Hospital, 00530 Helsinki, Finland; ari.salo@hus.fi

24 Department of Cardiology, Amsterdam University Medical Center, Location AMC, 1105 Amsterdam, The Netherlands; r.stieglis@amc.uva.nl

25 School of Education, Health and Social Studies, Dalarna University, S-79188 Falun, Sweden; ase@du.se

26 Centre for Clinical Research Dalarna, Uppsala University, S-79182 Falun, Sweden

27 Department of Prehospital Care, Region of Dalarna, S-79129 Falun, Sweden

28 Division of Prehospital Services, Oslo University Hospital, 0372 Oslo, Norway; ingvild@nakos.no

29 Faculty of Medicine, Institute of Clinical Medicine, University of Oslo, 0372 Oslo, Norway

30 Institute for Emergency Medicine, University Hospital Schleswig-Holstein, 24105 Kiel, Germany; wnent@eureca-two.eu (J.W.); jan-thorsten.graesner@uksh.de (J.-T.G.) 
31 Department of Anaesthesiology and Intensive Medicine, Medical Faculty, P.J. Safarik University, 04011 Kosice, Slovakia; strenkler@gmail.com

32 Department of Anesthesiology, University Hopspital Schleswig-Holstein, Campus Kiel, 24105 Kiel, Germany

33 School of Medicine, University of Namibia, Windhoek 10005, Namibia

34 Department of Anaesthesiology and Intensive Care Medicine, University Hospital and Medical Faculty of Cologne, 50931 Cologne, Germany; bernd.boettiger@uk-koeln.de

35 European Resuscitation Council (ERC), 2845 Niel, Belgium

36 Division of Cardiology, Fondazione IRCCS Policlinico San Matteo, 27100 Pavia, Italy

* Correspondence: enrico.baldi@unipv.it

\begin{abstract}
Introduction: The rapid use of an automated external defibrillator (AED) is crucial for increased survival after an out-of-hospital cardiac arrest (OHCA). Many factors could play a role in limiting the chance of an AED use. We aimed to verify the situation regarding AED legislation, the AED mapping system and first responders (FRs) equipped with an AED across European countries. Methods: We performed a survey across Europe entitled "European Study about AED Use by Lay Rescuers" (ENSURE), asking the national coordinators of the European Registry of Cardiac Arrest (EuReCa) program to complete it. Results: Nineteen European countries replied to the survey request for a population covering 128,297,955 inhabitants. The results revealed that every citizen can use an AED in 15 countries whereas a training certificate was required in three countries. In one country, only EMS personnel were allowed to use an AED. An AED mapping system and FRs equipped with an AED were available in only 11 countries. The AED use rate was $12-59 \%$ where AED mapping and FR systems were implemented, which was considerably higher than in other countries (0-7.9\%), reflecting the difference in OHCA survival. Conclusions: Our survey highlighted a heterogeneity in AED legislation, AED mapping systems and AED use in Europe, which was reflected in different AED use and survival.
\end{abstract}

Keywords: out-of-hospital cardiac arrest (OHCA); automated external defibrillator (AED) system; legislation; first responders

\title{
1. Introduction
}

Early cardiopulmonary resuscitation (CPR) and a rapid use of an automated external defibrillator (AED) are essential steps to improve survival after an out-of-hospital cardiac arrest (OHCA), as highlighted in the "Chain of Survival" [1,2]. Early defibrillation increases not only the rate of return of spontaneous circulation (ROSC) and survival but also a favorable neurological outcome at the hospital discharge, irrespective of it being a witnessed event, bystander CPR or an initial rhythm [3-5]. AED use by a bystander or first responders (FRs; i.e., police officers, firefighters, off-duty medical personnel and trained lay persons alerted when a patient experiences an OHCA nearby) before the arrival of emergency medical service (EMS) personnel is of a primary importance particularly when considering that the earlier the defibrillation, the higher the chance of survival [6-8]. This concept was proven in the early 2000s, when the public-access defibrillation (PAD) trial was carried out in the USA involving security officers after cardiac arrests in casinos [9] and has been continuously reinforced by numerous scientific publications subsequently released $[10,11]$. A recent meta-analysis of six observational studies, without a critical risk of bias, confirmed that bystander AED use was associated with a higher survival to the hospital discharge (all rhythms OR: 1.73 (95\% CI: 1.36, 2.18); shockable rhythms OR: 1.66 (95\% CI: 1.54, 1.79)) and a favorable neurological outcome (all rhythms OR: $2.12(95 \%$ CI: 1.36, 3.29); shockable rhythms OR: 2.37 (95\% CI: 1.58, 3.57)) [12].

Considering that no particular skills are needed to correctly use an AED [13] and no risks for rescuers are present [14,15], the guidelines have highlighted from 2015 onwards $[16,17]$ that the use of an AED even by untrained lay persons must be encouraged.

However, despite the well-established favorable role on survival and the resulting guideline recommendations, the rate of AED use is quite heterogenous among the different 
countries worldwide, including in Europe [18] where it is very low in many countries. Many factors could play a role in limiting the chance of AED use such as the availability of the AED, the presence of an FR alerting system and also local laws regulating the use of an AED by a bystander [19].

Therefore, we aimed to verify the situation regarding the legislation related to the use of an AED, an AED mapping system and the eventual dispatch of a first responder equipped with an AED across European countries. We also aimed to assess the eventual differences in the rates of AED use and the outcomes of patients among the countries according to the different organizational and legislation settings.

\section{Materials and Methods}

We performed a survey across Europe entitled "European Study About AED Use by Lay Rescuers" (ENSURE) asking primarily the 29 national coordinators of the European Registry of Cardiac Arrest (EuReCa) [20] program to fill in the questionnaire, referring to the EuReCa TWO period (October 2017-December 2017). The study was endorsed by the European Resuscitation Council (ERC) Research NET and by the Italian Resuscitation Council (IRC).

The questionnaire was divided into different parts (Supplementary File S1). The first part comprised general questions regarding the type of registry and the population covered; the second part focused on real-life data about OHCAs collected during the EuReCa TWO period and the third part queried the organizational and legislation setting both during the study period and at the time of survey completion (mid-2020). Considering the nature of the study, no further ethics approval was needed.

\section{Results}

We received replies from 19 European countries out of the 29 invited. The answers referred to 10 national registries and 9 regional or provincial registries for a total population of about 128,297,955 inhabitants. Regarding AED legislation, in 15 out of 19 countries, every citizen was allowed to use an AED whereas a training certificate was required in three countries. In one country, only EMS personnel were allowed to use an AED (Table 1 and Figure 1). An AED mapping system covering the whole nation was available in only 8 out of 19 countries and it was available only in certain areas in 3 out of 19 countries. Concerning the dispatch of first responders equipped with an AED, this was available in 11 out of 19 countries (Figure 1).

Table 1. AED legislation in different European countries updated in 2020 and the eventual differences compared with the EuReCa TWO period (late 2017).

\begin{tabular}{|c|c|c|c|c|c|c|}
\hline Country & $\begin{array}{l}\text { Is There Any } \\
\text { Special } \\
\text { Legislation on } \\
\text { the Use of } \\
\text { AEDs? }\end{array}$ & $\begin{array}{c}\text { Who Is Allowed to } \\
\text { Use an AED? }\end{array}$ & $\begin{array}{c}\text { Has the } \\
\text { Legislation } \\
\text { Changed after } \\
\text { December } \\
2017 ?\end{array}$ & $\begin{array}{l}\text { Are There } \\
\text { Legislation } \\
\text { Differences in } \\
\text { the Different } \\
\text { Regions of } \\
\text { Your Country? }\end{array}$ & $\begin{array}{c}\text { Was There An } \\
\text { aed Mapping } \\
\text { System in Your } \\
\text { Re- } \\
\text { gion/Country } \\
\text { in the Study } \\
\text { Period? }\end{array}$ & $\begin{array}{l}\text { Did the (EMS) } \\
\text { Activate FRS } \\
\text { Equipped with } \\
\text { an Aed in } \\
\text { Your Re- } \\
\text { gion/Country } \\
\text { in the Study } \\
\text { Period? }\end{array}$ \\
\hline $\begin{array}{l}\text { Belgium } \\
\text { Bosnia and }\end{array}$ & Yes & Everybody & No & No & No & No \\
\hline $\begin{array}{l}\text { Herzegov- } \\
\text { ina }\end{array}$ & No & Everybody & No & No & No & No \\
\hline Finland & No & Everybody & No & No & Yes & Yes \\
\hline France & Yes & Everybody & Yes ** & No & $\begin{array}{l}\text { Yes, only in } \\
\text { some areas }\end{array}$ & Yes \\
\hline Germany & No & Everybody & No & No & $\begin{array}{l}\text { Yes, only in a } \\
\text { few areas }\end{array}$ & $\begin{array}{l}\text { Yes, only in a } \\
\text { few areas }\end{array}$ \\
\hline
\end{tabular}


Table 1. Cont.

\begin{tabular}{|c|c|c|c|c|c|c|}
\hline Country & $\begin{array}{l}\text { Is There Any } \\
\text { Special } \\
\text { Legislation on } \\
\text { the Use of } \\
\text { AEDs? }\end{array}$ & $\begin{array}{l}\text { Who Is Allowed to } \\
\text { Use an AED? }\end{array}$ & $\begin{array}{l}\text { Has the } \\
\text { Legislation } \\
\text { Changed after } \\
\text { December } \\
\text { 2017? }\end{array}$ & $\begin{array}{l}\text { Are There } \\
\text { Legislation } \\
\text { Differences in } \\
\text { the Different } \\
\text { Regions of } \\
\text { Your Country? }\end{array}$ & $\begin{array}{c}\text { Was There An } \\
\text { aed Mapping } \\
\text { System in Your } \\
\text { Re- } \\
\text { gion/Country } \\
\text { in the Study } \\
\text { Period? }\end{array}$ & $\begin{array}{l}\text { Did the (EMS) } \\
\text { Activate FRS } \\
\text { Equipped with } \\
\text { an Aed in } \\
\text { Your Re- } \\
\text { gion/Country } \\
\text { in the Study } \\
\text { Period? }\end{array}$ \\
\hline Greece & Yes & $\underset{*}{\text { Everybody trained }}$ & No & No & No & No \\
\hline Ireland & No & Everybody & No & No & No & Yes \\
\hline Italy & Yes & Everybody trained & $\mathrm{No}^{* * *}$ & No & Yes & No \\
\hline Luxembourg & Yes & Everybody & No & No & Yes & Yes \\
\hline $\begin{array}{l}\text { The Nether- } \\
\text { lands }\end{array}$ & No & Everybody & No & No & $\begin{array}{l}\text { Yes, only in a } \\
\text { few areas }\end{array}$ & Yes \\
\hline Norway & No & Everybody & No & No & Yes & $\begin{array}{l}\text { Yes, only in a } \\
\text { few areas }\end{array}$ \\
\hline Romania & Yes & Everybody & No & No & No & Yes \\
\hline $\begin{array}{l}\text { Russian } \\
\text { Federation }\end{array}$ & No & $\begin{array}{l}\text { EMS providers } \\
\text { only }\end{array}$ & No & No & No & No \\
\hline Serbia & No & Everybody & No & No & Unknown & No \\
\hline Slovakia & No & Everybody & No & No & Yes & Yes \\
\hline Slovenia & Yes & Everybody & No & No & Yes & $\begin{array}{l}\text { Yes, only in a } \\
\text { few areas }\end{array}$ \\
\hline Spain & Yes & Everybody trained & No & No & No & No \\
\hline Sweden & No & Everybody & No & No & Yes & Yes \\
\hline Switzerland & No & Everybody & No & No & Yes & Yes \\
\hline
\end{tabular}

* In Greece, the law allows only trained lay persons to use an AED but it also establishes that anyone who offers immediate help in goodwill to a cardiac arrest victim cannot be prosecuted. "* A "Good Samaritan" law allowing all citizens to use an AED was issued in July 2020 in France. ${ }^{* * *}$ In Italy, the Parliament approved a "Good Samaritan" law in late July 2021, which is currently being implemented.

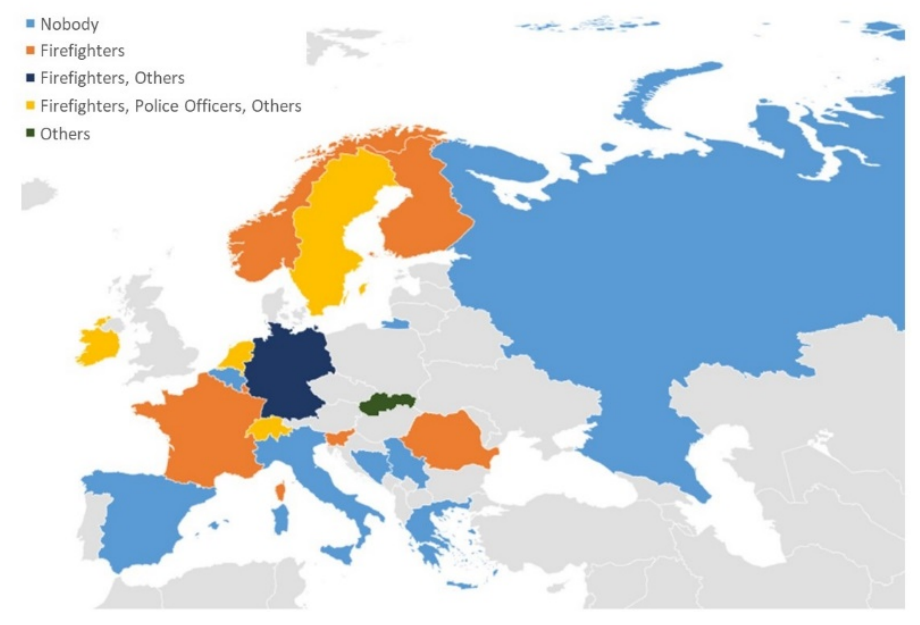

Figure 1. Cont. 


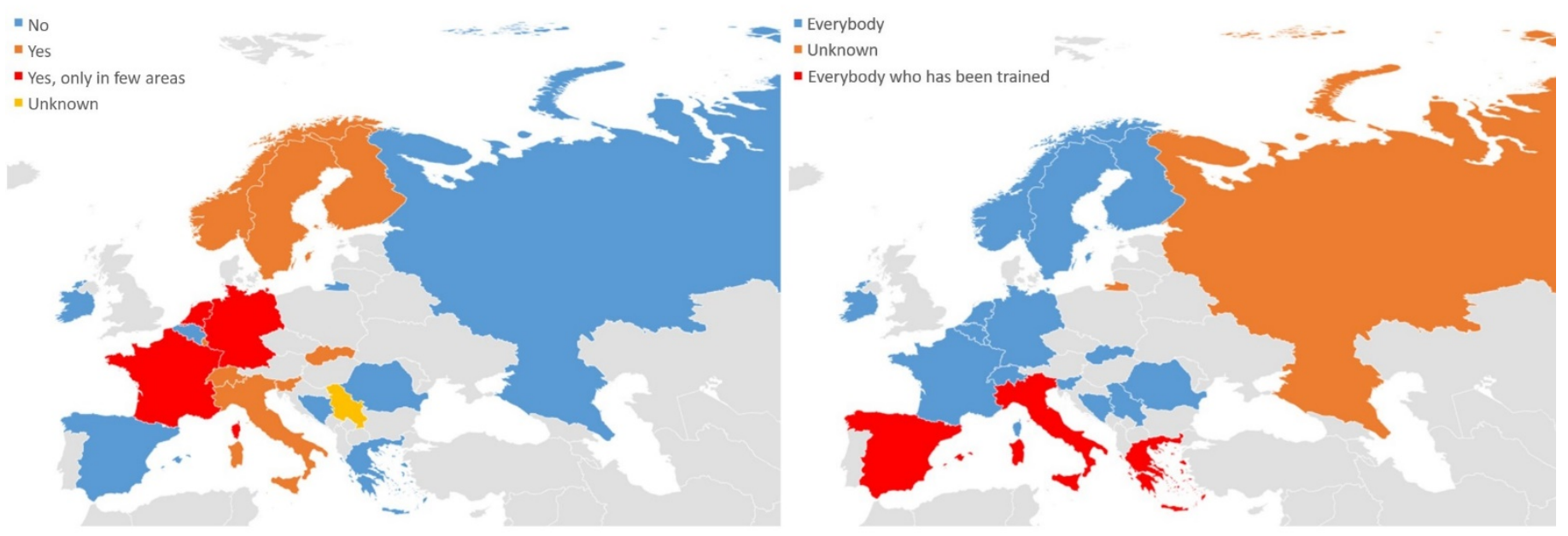

Figure 1. Graphical representation across the different European countries regarding who is, equipped with an AED, activated by the EMS, if there was an AED mapping system and who is allowed to use an AED.

The data regarding the number of OHCA occurred, the use of an AED before EMS arrival, the ROSC and survival across the different european countries during the EuReCa TWO period (October 2017-December 2017) are presented in Table 2. 
Table 2. Number of OHCAs, AED use, ROSCs and survival across the different European countries during the EuReCa TWO period (October 2017-December 2017).

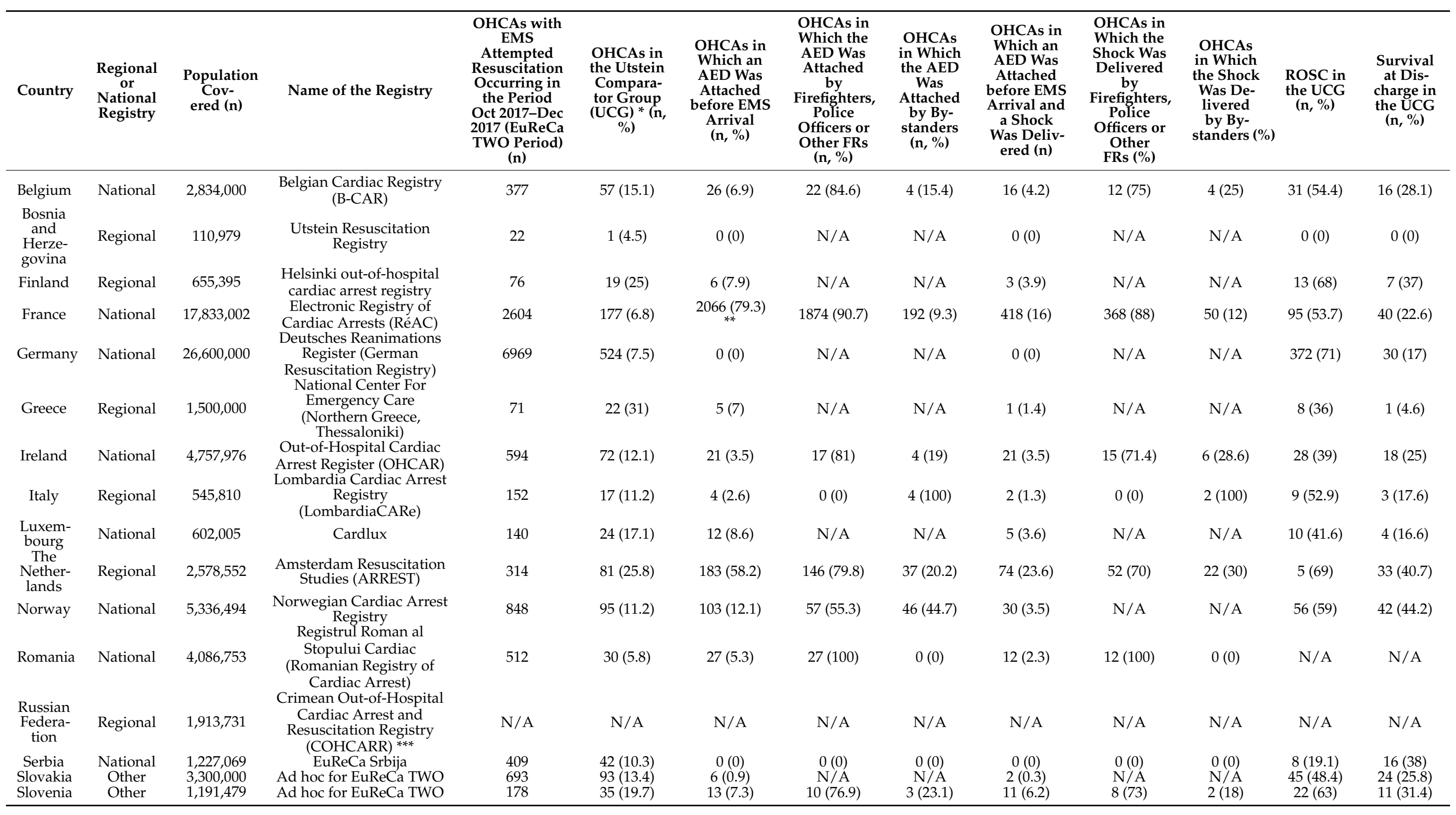


Table 2. Cont.

\begin{tabular}{|c|c|c|c|c|c|c|c|c|c|c|c|c|c|}
\hline Country & $\begin{array}{c}\text { Regional } \\
\text { or } \\
\text { National } \\
\text { Registry }\end{array}$ & $\begin{array}{l}\text { Population } \\
\text { Cov- } \\
\text { ered (n) }\end{array}$ & Name of the Registry & $\begin{array}{c}\text { OHCAs with } \\
\text { EMS } \\
\text { Attempted } \\
\text { Resuscitation } \\
\text { Occurring in } \\
\text { the Period } \\
\text { Oct 2017-Dec } \\
\text { 2017 (EuReCa } \\
\text { TWO Period) } \\
\text { (n) }\end{array}$ & $\begin{array}{c}\text { OHCAs in } \\
\text { the Utstein } \\
\text { Compara- } \\
\text { tor Group } \\
\text { (UCG) }{ }^{*}(\mathrm{n}, \\
\%)\end{array}$ & $\begin{array}{c}\text { OHCAs in } \\
\text { Which an } \\
\text { AED Was } \\
\text { Attached } \\
\text { before EMS } \\
\text { Arrival } \\
(\mathrm{n}, \%)\end{array}$ & $\begin{array}{c}\text { OHCAs in } \\
\text { Which the } \\
\text { AED Was } \\
\text { Attached } \\
\text { by } \\
\text { Firefighters, } \\
\text { Police } \\
\text { Officers or } \\
\text { Other FRs } \\
\text { (n, \%) }\end{array}$ & $\begin{array}{c}\text { OHCAs } \\
\text { in Which } \\
\text { the AED } \\
\text { Was } \\
\text { Attached } \\
\text { by By- } \\
\text { standers } \\
(\mathrm{n}, \%)\end{array}$ & $\begin{array}{l}\text { OHCAs in } \\
\text { Which an } \\
\text { AED Was } \\
\text { Attached } \\
\text { before EMS } \\
\text { Arrival and } \\
\text { a Shock } \\
\text { Was Deliv- } \\
\text { ered (n) }\end{array}$ & $\begin{array}{l}\text { OHCAs in } \\
\text { Which the } \\
\text { Shock Was } \\
\text { Delivered } \\
\text { by } \\
\text { Firefighters, } \\
\text { Police } \\
\text { Officers or } \\
\text { Other } \\
\text { FRs (\%) }\end{array}$ & $\begin{array}{l}\text { OHCAs } \\
\text { in Which } \\
\text { the Shock } \\
\text { Was De- } \\
\text { livered } \\
\text { by By- } \\
\text { standers (\%) }\end{array}$ & $\begin{array}{l}\text { ROSC in } \\
\text { the UCG } \\
(\mathrm{n}, \%)\end{array}$ & $\begin{array}{c}\text { Survival } \\
\text { at Dis- } \\
\text { charge in } \\
\text { the UCG } \\
\text { (n, \%) }\end{array}$ \\
\hline Spain & National & $42,750,768$ & $\begin{array}{c}\text { Out-of-Hospital Spanish } \\
\text { Registry of Cardiac Arrest } \\
\text { (OHSCAR) }\end{array}$ & 2148 & 342 (15.9) & $75(3.5)$ & 44 (58.7) & $31(41.3)$ & $38(1.8)$ & $13(34.2)$ & $25(65.8)$ & $209(61.1)$ & $100(29.2)$ \\
\hline Sweden & National & $10,120,242$ & $\begin{array}{c}\text { The Swedish Registry of } \\
\text { Cardiopulmonary } \\
\text { Resuscitation (SRCR) }\end{array}$ & 1466 & $171(11.7)$ & $336(25)$ & $269(80)$ & $44(13.1)$ & $84(5.7)$ & $46(55)$ & $27(32)$ & $96(56.1)$ & $101(59.1)$ \\
\hline $\begin{array}{l}\text { Switzer- } \\
\text { land }\end{array}$ & Regional & 353,700 & $\begin{array}{c}\text { Ticino Registry Cardiac } \\
\text { Arrest (TiReCA) }\end{array}$ & 53 & $9(17)$ & $19(35.8)$ & $12(63.1)$ & $7(36.8)$ & $2(3.8)$ & $1(50)$ & $1(50)$ & $4(44.4)$ & $2(22.2)$ \\
\hline
\end{tabular}

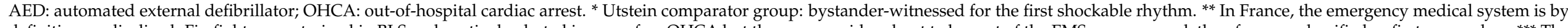

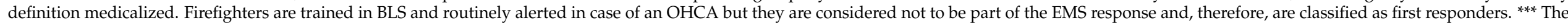

Crimean Out-of-Hospital Cardiac Arrest and Resuscitation Registry (COHCARR) started to collect data from 1 January 2018 onwards. 


\section{Discussion}

Our study has presented data regarding the legislations regulating AED use, the AED mapping systems and AED use across Europe, highlighting a great heterogeneity across European countries. This is reflected in important variations in AED use and OHCA patient survival in different countries.

\subsection{The Importance of the Legislation Rule}

It is reasonable to assume that the rate of AED use is influenced by the type of legislation regulating the use of an AED by lay persons [19] although evidence in the literature on this topic is limited. Notably, in those countries where a certificate is needed for lay persons to be allowed to use an AED, the use of an AED is low (between 2.4\% and 5\%) [21,22] compared with those countries where a "Good Samaritan" law is in force and all citizens can freely use an AED if necessary (about 15-20\% of an AED use before EMS arrival) [10,23-25]. Concerning Europe, the last survey about legislation rules on AED use dates back 11 years [26]. It highlighted that the use of an AED was allowed for all the citizens in one third of interviewed countries, for citizens with a certificate in another third and only for physicians or EMS personnel in the last third. Our study outlined that the situation has considerably improved in ten years: in about $80 \%$ of the countries, every citizen was allowed to use an AED. However, a training certificate was still required in three countries (Greece, Italy and Spain) and in one (Russia Federation) only EMS personnel were allowed to use an AED. Considering that six years have passed since the ERC 2015 guidelines were issued, we believe that the situation is quite alarming and suggests that several countries need to rapidly adhere to the recommendations allowing untrained bystanders to use an AED, thus increasing the rate of lay defibrillation and, therefore, the chance of survival of OHCA patients.

\subsection{AED Mapping and First Responder Systems}

The chance of receiving an early defibrillation depends on the availability of PADs [27]. Considering that the survival to discharge decreases for every minute of delay to defibrillation [17], it is crucial to retrieve an AED as soon as possible [28]. For this reason, the guidelines since 2015 have recommended that publicly accessible AEDs are registered and mapped so that dispatchers can direct CPR providers to the closest AED, optimizing the system response [29]. Our survey highlighted that an AED mapping system was available in just over half of the countries and this percentage dropped to only $40 \%$ if we considered only the countries with an AED mapping system available for the whole nation. No system mapping AEDs was available in 8 out of 19 countries. This aspect should be improved to increase the chance that an AED is brought to the scene in case of an OHCA. From a scientific point of view, the possibility of merging the location of the OHCA and the position of the AED by using both cardiac arrest registries and AED mapping systems could allow the development of new algorithms to relocate the AEDs with the intent to improve optimal coverage [30] to use more properly the AEDs already available without necessarily increasing their numbers as well as to exploit new innovative methods to get an AED to the scene such as the use of drones [31]. Furthermore, a crucial role in enhancing the possibility of providing early defibrillation is played by FRs $[6,25,32-34]$. FRs are commonly divided into "professional FRs" such as police officers, firefighters or off-duty medical personnel and "citizen FRs" meaning trained lay persons [7]. For this latter category, the only chance of using an AED depends on the availability of an AED on site and the possibility of receiving instructions from the dispatch center (or by the alerting APP) about the closest AED, stressing once again the importance of AED mapping. For the professional FRs, the situation is different because they are often equipped with an AED and can bring the defibrillator to the OHCA scene when alerted, resulting in a reduction of the time to the first defibrillation, which is associated with an increased chance of survival [35]. The effectiveness and the capability of the FR system to increase survival is already well-documented [8]. In our survey, we found that only in 11 out of 19 countries 
were the professional FRs alerted by the EMS equipped with an AED, stressing the need to improve this aspect throughout Europe.

\subsection{Differences in AED Use, ROSC and Survival across Europe}

Important differences among the countries regarding the rate of AED use before the arrival of the EMS have been already evidenced [18]. Our survey confirmed that in those countries where the law permits only trained bystanders to use an AED such as Greece, Italy and Spain, the chance of being defibrillated before the arrival of the EMS is particularly low (from 2.6 to $7 \%$ ). However, the percentage of AED use before the arrival of the EMS appeared to be deeply varied across the European countries and it was low also in several countries where everybody is allowed to use an AED (e.g., Belgium, Ireland, Romania, Slovakia and Slovenia), suggesting that probably it is not only a matter of law. Our survey hinted that in countries where AED mapping and an FRs system are implemented alongside a permissive law, the rate of AED use was higher. This was particularly clear in several countries such as The Netherlands, Norway, Sweden and Switzerland, where systems to save a life were implemented many years ago $[6,10,34]$. In these countries, the rate of AED use was between 12 and 59\%, considerably higher than in other countries (from 0 to $7.9 \%$ ). All the above is perfectly in line with the latest ERC guidelines, which, for the very first time, have dedicated an entire chapter to the importance of the "Systems saving lives" [28], embracing the philosophy of the European Resuscitation Academy (ERA) and the Global Resuscitation Alliance (GRA) [36,37].

\subsection{Limitations}

Our study has limitations. The first is that we received data from 19 European countries; this does not represent all the countries present in Europe. However, considering that the registries included covered more than 125 million people, we believe that our study could be considered to be representative of the European situation. The second limitation is that we decided to refer, regarding OHCA data, to the EuReCa TWO period. This was chosen to consider the same time period in all the countries facilitating data retrieving and because a few registries collected data only during the EuReCa surveys, allowing an increase in the data collected for the present study. We decided to overcome this limitation by allowing the presentation of past data and to ask in the survey for the organizational and legislation setting both during the EuReCa TWO period and at the time of the survey completion (mid-2020). This allowed us to present data representing as much as possible the actual European situation. Considering this type of situation is constantly evolving, we marked the eventual subsequent changes that intervened after the survey completion, as seen in Table 1.

\section{Conclusions}

Our survey highlighted a great heterogeneity in terms of the legislations regulating the use of an AED, AED mapping systems and AED use across Europe, therefore limiting the OHCA survival in many European regions and countries. Considering the undoubted importance of all these three actions to maximize the chance of survival after an OHCA, we strongly suggest the following to all the European countries and their governments:

1. To issue a law that allow all citizens, including untrained ones, to use an AED in the case of a suspected OHCA and protecting them against any legal consequences.

2. To make an AED map compulsory that includes all public AEDs and that is linked to the emergency medical system dispatch center.

3. To implement FR systems, including both citizens trained in CPR and professional FRs (i.e., police officers, firefighters, off-duty medical personnel) possibly equipped with an AED, to increase the rate of defibrillation before the arrival of the EMS.

4. To unify cardiac arrest registries among European countries to harmonize data collection and better comprehend the European strategies to implement an improved OHCA survival. 
Supplementary Materials: The following are available online at https://www.mdpi.com/article/10 $.3390 /$ jcm10215018/s1, Supplementary File S1: ENSURE study questionnaire.

Author Contributions: Conceptualization, E.B., N.B.G., G.R. and S.S.; methodology, E.B. and S.S.; formal analysis, E.B. and S.S.; investigation, H.A., V.C., A.B., R.C., D.C., C.C., J.G., A.M., P.M., O.N., M.Q., V.R., F.R.O., A.S. (Ari Salo), R.S., A.S. (Anneli Strömsöe), I.T., S.T. and J.W.; data curation, E.B.; writing - original draft preparation, E.B.; writing—review and editing, J.-T.G., B.W.B. and S.S.; supervision, S.S. All authors have read and agreed to the published version of the manuscript.

Funding: This research received no external funding. The publication fee was covered by Italian Resuscitation Council with funds for dissemination within the "iProcureSecurity" H2020 project (Grant Agreement No 833291).

Institutional Review Board Statement: The study was conducted according to the guidelines of the Declaration of Helsinki. Each cardiac arrest registry that provided the data for the present study has been approved by the relevant ethics committee in accordance with its national law. No further ethics approval was required.

Informed Consent Statement: Considering the type of the study, no specific written consent was needed.

Acknowledgments: The present survey was promoted by the Italian Resuscitation Council and has been endorsed by the ERC Research NET.

Conflicts of Interest: J.W. is member of the German Resuscitation Registry steering committee and EuReCa study management team and has no financial COIs to declare. J.-T.G. is member of the German Resuscitation Registry steering committee, EuReCa project leader and obtained funding for the Institute for Emergency Medicine, University Hospital Schleswig-Holstein from Corpuls (GS Stemple) and personal speaker fees and travel costs from ZOLL, Corpuls, Philips and Weinmann-emergency. B.W.B. is treasurer of the European Resuscitation Council (ERC), Chairman of the German Resuscitation Council (GRC), Member of the Advanced Life Support (ALS) Task Force of the International Liaison Committee on Resuscitation (ILCOR), Member of the Executive Committee of the German Interdisciplinary Association for Intensive Care and Emergency Medicine (DIVI), Founder of the "Deutsche Stiftung Wiederbelebung", Co-Editor of "Resuscitation", Editor of the Journal "Notfall + Rettungsmedizin" and Co-Editor of the Brazilian Journal of Anesthesiology. He received fees for lectures from the following companies: Forum für medizinische Fortbildung (FomF), Baxalta Deutschland GmbH, ZOLL Medical Deutschland GmbH, C.R. Bard GmbH, GS Elektromedizinische Geräte G. Stemple GmbH, Novartis Pharma GmbH, Philips GmbH Market $\mathrm{DACH}$ and Bioscience Valuation BSV GmbH. The other authors reported no conflict of interest.

\section{References}

1. Cummins, R.O.; Ornato, J.P.; Thies, W.H.; Pepe, P.E. Improving Survival From Sudden Cardiac Arrest: The "Chain of Survival” Concept. Circ. AHA Statement 1991, 83, 1831-1843.

2. Deakin, C.D. The chain of survival: Not all links are equal. Resuscitation 2018, 126, 80-82. [CrossRef]

3. Weisfeldt, M.L.; Sitlani, C.M.; Ornato, J.P.; Rea, T.; Aufderheide, T.P.; Davis, D.; Dreyer, J.; Hess, E.P.; Jui, J.; Maloney, J.; et al. Survival After Application of Automatic External Defibrillators Before Arrival of the Emergency Medical System. Evaluation in the Resuscitation Outcomes Consortium Population of 21 Million. J. Am. Coll. Cardiol. 2010, 55, 1713-1720. [CrossRef] [PubMed]

4. Kishimori, T.; Kiguchi, T.; Kiyohara, K.; Matsuyama, T.; Shida, H.; Nishiyama, C.; Kobayashi, D.; Okabayashi, S.; Shimamoto, T.; Hayashida, S.; et al. Public-access automated external defibrillator pad application and favorable neurological outcome after out-of-hospital cardiac arrest in public locations: A prospective population-based propensity score-matched study. Int. J. Cardiol. 2020, 299, 140-146. [CrossRef] [PubMed]

5. Savastano, S.; Baldi, E.; Compagnoni, S.; Fracchia, R.; Ristagno, G.; Grieco, N. The automated external defibrillator, an underused simple life-saving device: A review of the literature. A joint document from the Italian Resuscitation Council (IRC) and Associazione Italiana di Aritmologia e Cardiostimolazione (AIAC). J. Cardiovasc. Med. 2020, 21, 733-739. [CrossRef] [PubMed]

6. Caputo, M.L.; Muschietti, S.; Burkart, R.; Benvenuti, C.; Conte, G.; Regoli, F.; Mauri, R.; Klersy, C.; Moccetti, T.; Auricchio, A. Lay persons alerted by mobile application system initiate earlier cardio-pulmonary resuscitation: A comparison with SMS-based system notification. Resuscitation 2017, 114, 73-78. [CrossRef] [PubMed]

7. Baldi, E.; Caputo, M.L.; Auricchio, A.; Vanetta, C.; Cresta, R.; Benvenuti, C. A quantitative assessment of the contribution of "citizen First Responder" in the adult out-of-hospital chain of survival during COVID-19 pandemic. Resuscitation 2021, 166, 41-42. [CrossRef] [PubMed] 
8. Oving, I.; de Graaf, C.; Masterson, S.; Koster, R.W.; Zwinderman, A.H.; Stieglis, R.; AliHodzic, H.; Baldi, E.; Betz, S.; Cimpoesu, D.; et al. European first responder systems and differences in return of spontaneous circulation and survival after out-of-hospital cardiac arrest: A study of registry cohorts. Lancet Reg. Health-Eur. 2021, 1, 100004. [CrossRef]

9. Hallstrom, A.P.; Ornato, J.P.; Weisfeldt, M.; Travers, A.H.; Christenson, J.; McBurnie, M.; Zalenski, R.; Becker, L.B.; Schron, E.; Proschan, M. Public-Access Defibrillation and Survival after Out-of-Hospital Cardiac Arrest. N. Engl. J. Med. 2004, 351, 637-646.

10. Ringh, M.; Jonsson, M.; Nordberg, P.; Fredman, D.; Hasselqvist-Ax, I.; Håkansson, F.; Claesson, A.; Riva, G.; Hollenberg, J. Survival after Public Access Defibrillation in Stockholm, Sweden-A striking success. Resuscitation 2015, 91, 1-7. [CrossRef]

11. Kiyohara, K.; Kitamura, T.; Sakai, T.; Nishiyama, C.; Nishiuchi, T.; Hayashi, Y.; Sakamoto, T.; Marukawa, S.; Iwami, T. Publicaccess AED pad application and outcomes for out-of-hospital cardiac arrests in Osaka, Japan. Resuscitation 2016, 106, 70-75. [CrossRef] [PubMed]

12. Holmberg, M.J.; Vognsen, M.; Andersen, M.S.; Donnino, M.W.; Andersen, L.W. Bystander automated external defibrillator use and clinical outcomes after out-of-hospital cardiac arrest: A systematic review and meta-analysis. Resuscitation 2017, 120, 77-87. [CrossRef] [PubMed]

13. Yeung, J.; Okamoto, D.; Soar, J.; Perkins, G.D. AED training and its impact on skill acquisition, retention and performance-A systematic review of alternative training methods. Resuscitation 2011, 82, 657-664. [CrossRef]

14. Hoke, R.S.; Heinroth, K.; Trappe, H.J.; Werdan, K. Is external defibrillation an electric threat for bystanders? Resuscitation 2009, 80, 395-401. [CrossRef]

15. Baldi, E.; Contri, E. Using an AED in particular environments: Is it safe or not? Suggestions for lay people and their instructors. Resuscitation 2016, 106, e25. [CrossRef] [PubMed]

16. Perkins, G.D.; Graesner, J.T.; Semeraro, F.; Olasveengen, T.; Soar, J.; Lott, C.; Van de Voorde, P.; Madar, J.; Zideman, D.; Mentzelopoulos, S.; et al. European Resuscitation Council Guidelines 2021: Executive summary. Resuscitation 2021, 161, 1-60. [CrossRef]

17. Perkins, G.D.; Handley, A.J.; Koster, R.W.; Castrén, M.; Smyth, M.A.; Olasveengen, T.; Monsieurs, K.G.; Raffay, V.; Gräsner, J.T.; Wenzel, V.; et al. European Resuscitation Council Guidelines for Resuscitation 2015. Section 2. Adult basic life support and automated external defibrillation. Resuscitation 2015, 95, 81-99. [CrossRef]

18. Kiguchi, T.; Okubo, M.; Nishiyama, C.; Maconochie, I.; Ong, M.E.H.; Kern, K.B.; Wyckoff, M.H.; McNally, B.; Christensen, E.; Tjelmeland, I.; et al. Out-of-hospital cardiac arrest across the World: First report from the International Liaison Committee on Resuscitation (ILCOR). Resuscitation 2020, 152, 39-49. [CrossRef]

19. Baldi, E.; Savastano, S. AED use before EMS arrival: When survival becomes a matter of law and system in Italy, which can be improved. Eur. Heart J. 2018, 39, 1664. [CrossRef]

20. Gräsner, J.T.; Wnent, J.; Herlitz, J.; Perkins, G.D.; Lefering, R.; Tjelmeland, I.; Koster, R.W.; Masterson, S.; Rossell-Ortiz, F.; Maurer, H.; et al. Survival after out-of-hospital cardiac arrest in Europe-Results of the EuReCa TWO study. Resuscitation 2020, 148, 218-226. [CrossRef]

21. Masterson, S.; Wright, P.; O’Donnell, C.; Vellinga, A.; Murphy, A.W.; Hennelly, D.; Sinnott, B.; Egan, J.; O’Reilly, M.; Keaney, J.; et al. Urban and rural differences in out-of-hospital cardiac arrest in Ireland. Resuscitation 2015, 91, 42-47. [CrossRef] [PubMed]

22. Irfan, F.B.; Bhutta, Z.A.; Castren, M.; Straney, L.; Djarv, T.; Tariq, T.; Thomas, S.H.; Alinier, G.; Al Shaikh, L.; Owen, R.C.; et al. Epidemiology and outcomes of out-of-hospital cardiac arrest in Qatar: A nationwide observational study. Int. J. Cardiol. 2016, 223, 1007-1013. [CrossRef] [PubMed]

23. Mauri, R.; Burkart, R.; Benvenuti, C.; Caputo, M.L.; Moccetti, T.; Del Bufalo, A.; Gallino, A.; Casso, C.; Anselmi, L.; Cassina, T.; et al. Better management of out-of-hospital cardiac arrest increases survival rate and improves neurological outcome in the Swiss Canton Ticino. Europace 2016, 18, 398-404. [CrossRef]

24. Kragholm, K.; Wissenberg, M.; Mortensen, R.N.; Hansen, S.M.; Malta Hansen, C.; Thorsteinsson, K.; Rajan, S.; Lippert, F.; Folke, F.; Gislason, G.; et al. Bystander Efforts and 1-Year Outcomes in Out-of-Hospital Cardiac Arrest. N. Engl. J. Med. 2017, 376, 1737-1747. [CrossRef] [PubMed]

25. Pijls, R.W.M.; Nelemans, P.J.; Rahel, B.M.; Gorgels, A.P.M. A text message alert system for trained volunteers improves out-ofhospital cardiac arrest survival. Resuscitation 2016, 105, 182-187. [CrossRef]

26. Bahr, J.; Bossaert, L.; Handley, A.; Koster, R.; Vissers, B.; Monsieurs, K. AED in Europe. Report on a survey. Resuscitation 2010, 81, 168-174. [CrossRef] [PubMed]

27. Hansen, C.M.; Lippert, F.K.; Wissenberg, M.; Weeke, P.; Zinckernagel, L.; Ruwald, M.H.; Karlsson, L.; Gislason, G.H.; Nielsen, S.L.; Køber, L.; et al. Temporal trends in coverage of historical cardiac arrests using a volunteer-based network of automated external defibrillators accessible to laypersons and emergency dispatch centers. Circulation 2014, 130, 1859-1867. [CrossRef]

28. Semeraro, F.; Greif, R.; Böttiger, B.W.; Burkart, R.; Cimpoesu, D.; Georgiou, M.; Yeung, J.; Lippert, F.; Lockey, A.S.; Olasveengen, T.M.; et al. European Resuscitation Council Guidelines 2021: Systems saving lives. Resuscitation 2021, 161, 80-97. [CrossRef]

29. Monsieurs, K.R.G.; Nolan, J.P.; Bossaert, L.L.; Greif, R.; Maconochie, I.K.; Nikolaou, N.I.; Perkins, G.D.; Soar, J.; Truhlář, A.; Wyllie, J.; et al. European Resuscitation Council Guidelines for Resuscitation 2015. Section 1. Executive summary. Resuscitation 2015, 95, 1-80. [CrossRef] 
30. Tierney, N.J.; Reinhold, H.J.; Mira, A.; Weiser, M.; Burkart, R.; Benvenuti, C.; Auricchio, A. Novel relocation methods for automatic external defibrillator improve out-of-hospital cardiac arrest coverage under limited resources. Resuscitation 2018, 125, 83-89. [CrossRef]

31. Derkenne, C.; Jost, D.; Miron De L'Espinay, A.; Corpet, P.; Frattini, B.; Hong, V.; Lemoine, F.; Jouffroy, R.; Roquet, F.; Marijon, E.; et al. Automatic external defibrillator provided by unmanned aerial vehicle (drone) in Greater Paris: A real worldbased simulation. Resuscitation 2021, 162, 259-265. [CrossRef] [PubMed]

32. Ringh, M.; Rosenqvist, M.; Hollenberg, J.; Jonsson, M.; Fredman, D.; Nordberg, P.; Järnbert-Pettersson, H.; Hasselqvist-Ax, I.; Riva, G.; Svensson, L. Mobile-Phone Dispatch of Laypersons for CPR in Out-of-Hospital Cardiac Arrest. N. Engl. J. Med. 2015, 372, 2316-2325. [CrossRef]

33. Stein, P.; Spahn, G.H.; Müller, S.; Zollinger, A.; Baulig, W.; Brüesch, M.; Seifert, B.; Spahn, D.R. Impact of city police layperson education and equipment with automatic external defibrillators on patient outcome after out of hospital cardiac arrest. Resuscitation 2017, 118, 27-34. [CrossRef]

34. Zijlstra, J.A.; Stieglis, R.; Riedijk, F.; Smeekes, M.; van der Worp, W.E.; Koster, R.W. Local lay rescuers with AEDs, alerted by text messages, contribute to early defibrillation in a Dutch out-of-hospital cardiac arrest dispatch system. Resuscitation 2014, 85, 1444-1449. [CrossRef] [PubMed]

35. Krammel, M.; Lobmeyr, E.; Sulzgruber, P.; Winnisch, M.; Weidenauer, D.; Poppe, M.; Datler, P.; Zeiner, S.; Keferboeck, M.; Eichelter, J.; et al. The impact of a high-quality basic life support police-based first responder system on outcome after out-ofhospital cardiac arrest. PLoS ONE 2020, 15, e0233966. [CrossRef] [PubMed]

36. Baldi, E.; Contri, E.; Burkart, R.; Bywater, D.; Duschl, M. The three dimension model of the out-of-hospital cardiac arrest. Resuscitation 2019, 138, 44-45. [CrossRef]

37. Nadarajan, G.D.; Tiah, L.; Ho, A.F.W.; Azazh, A.; Castren, M.K.; Chong, S.L.; El Sayed, M.J.; Hara, T.; Leong, B.S.; Lippert, F.K.; et al. Global resuscitation alliance utstein recommendations for developing emergency care systems to improve cardiac arrest survival. Resuscitation 2018, 132, 85-89. [CrossRef] [PubMed] 